Article

\title{
Price and Output Elasticities of Energy Demand for Industrial Sectors in OECD Countries ${ }^{+}$
}

\author{
Boyoon Chang ${ }^{1}\left(\mathbb{D}\right.$, Sung Jin Kang ${ }^{2, *} \mathbb{1}$ and Tae Yong Jung ${ }^{3}$ \\ 1 Capital Economic Consulting Group, Lee \& Ko Law Firm, Seoul 04532, Korea; boyoonchang@gmail.com \\ 2 Department of Economics and Graduate School of Energy and Environment, Korea University, \\ Seoul 02841, Korea \\ 3 Graduate School of International Studies, Yonsei University, Seoul 03722, Korea; tyjung00@yonsei.ac.kr \\ * Correspondence: sjkang@korea.ac.kr; Tel.: +82-2-3290-2225 \\ + The opinions and contents in this paper solely represent those of the authors and do not represent the views \\ of the Lee \& Ko Law Firm or Lee \& Ko Law Firm Capital Economic Consulting Group.
}

Received: 15 February 2019; Accepted: 18 March 2019; Published: 25 March 2019

check for updates

\begin{abstract}
The price and output elasticities of energy demand continue to be of interest to academia and policy institutions, having been estimated in previous studies. However, the estimated results show some inconsistencies, especially at the sectoral level, across countries. Based on our conjecture that those inconsistencies are mainly due to the effect of contingent energy intensities and partially to different units of analysis, we narrowed the analysis to the industry level and classified 16 industries into energy-intensive and less energy-intensive groups. The effects of price and output on energy demand were then compared between these two groups using 274 industry panel data across 20 Organization for Economic Cooperation and Development (OECD) countries from 1978 to 2013. The results showed that the price elasticity of energy demand was consistently lower in the energy-intensive group than in the less energy-intensive group, whereas the output elasticity of energy demand was higher in the energy-intensive group than in the less energy-intensive group. Using panel differences and system generalized method of moments estimations, the dynamic elasticities of energy demand were also estimated. Energy demand in reaction to both price and output changes appeared to be more elastic in the long term than in the short term for both energy-intensive and less energy-intensive groups. These findings could be a useful reference for policy makers to deploy separate energy policies for different industries aiming for different temporal effects.
\end{abstract}

Keywords: OECD countries; price elasticity of energy demand; output elasticity of energy demand; industrial sectors

\section{Introduction}

\subsection{Background and Objective}

Energy consumption is essential for economic growth, especially in industrial sectors with high energy consumption. The International Energy Agency (IEA) reported that industrial sectors in Organization for Economic Cooperation and Development (OECD) countries alone consumed 792 million tons of oil equivalent in 2015, which accounted for $21.8 \%$ of the OECD countries' total final-energy consumption [1]. As most of these industrial sectors still use fossil fuels as their primary energy source, economic growth has been historically associated with environmental degradation, such as global warming and climate change. In response, policies to provide flexibility in moderating energy price or incentives to promote renewable energy application are currently in use across many countries.

The effectiveness of price policy relies on the precise measurement of the price elasticity of energy demand. Earlier studies estimated energy demand with respect to price and income changes. However, 
the estimated results showed some inconsistencies, varying in their level of aggregation used to measure the energy demand. Many studies measured country-level aggregated energy consumption rather than sectoral- or industry-level consumption, and focused on a specific country rather than across panel countries. Whereas such time-series studies could provide comprehensive insights into the macro-energy demand response of a particular country, panel data can be used to control for country invariant variables that cannot be measured $[2,3]$.

Several studies explored energy consumption patterns at the sectoral level, which includes residential, industry, and transportation. To the best of our knowledge, none of these studies deeply examined the sub-sectoral or industry level and classified industries according to the intensity of energy consumption. The national authorities of OECD countries tend to design and implement uniform energy policies for the industrial sector as a whole, rather than specific energy policies targeted to each industry. Considering the heterogeneous energy consumption patterns among energy-intensive and less energy-intensive industries, which often play a critical role in the production process, energy policies that do not consider these differences would either be infeasible or ineffective.

As such, we aimed to verify whether structurally different industries exhibit different price or income elasticity of energy demand. We examined if industries could further be classified into an energy-intensive or less energy-intensive groups and whether the price and income elasticities differed significantly between these two groups. To achieve this goal, we tried to find the determinants of energy demand by examining historical energy consumption patterns of OECD countries in terms of energy prices and industrial value-added. We further investigated how the short- and long-term energy consumptions of the energy-intensive and less energy-intensive groups were affected differently by dynamic changes in energy prices and value-added. As the data exhibited relatively large cross-sectional components compared to time-series components, we used panel difference and system generalized method of moments (GMM) estimators, specifically developed for this kind of dataset, and controlled for the endogeneity of the lagged dependent variables included as one of the explanatory variables [4-6].

The remainder of this paper is organized as follows. The next section reviews the previous literature on the price and output elasticities of energy demand. Section 2 outlines the theoretical framework used to measure the price and output elasticities of demand and the empirical methodology. Section 3 summarizes the empirical findings and compares the short- and long-term elasticities between the energy-intensive and less energy-intensive groups. Finally, Section 4 concludes with our discussion of policy implications.

\subsection{Literature Review}

Earlier studies analyzed the time-series data of a specific country [7,8]. Bentzen and Engstead [7] used Danish data over a 43-year span from 1948 to 1990 to estimate the aggregate energy demand as a function of real gross domestic product (GDP), real price of energy demand, and temperature. They concluded that the short- and long-term output elasticities were 0.666 and 1.213 , respectively, and the corresponding own-price elasticities were -0.135 and -0.465 , respectively. Hunt and Ninomiya [8] identified the long-term relationship among primary energy demand, GDP, and real energy prices in Japan over 115 years from 1887 to 2001 using the Autoregressive Distributive Lag (ARDL) model. The estimated long-term output and elasticities were 1.06 and -0.20 , respectively.

Some studies analyzed the country-level energy demand using panel data [9-11]. Al-Rabbaie and Hunt [9] used the ARDL model for 17 OECD countries from 1960 to 2003 to show that the long-term output and price elasticities ranged from 0.5 to 1.5 and -0.1 to -0.4 , respectively. Adeyemi and Hunt [10] used the data for 15 OECD countries over 42 years from 1962 to 2003 and calculated both the price and output elasticities of energy demand in the long term. Assuming asymmetry price responses with no time effects, the long-term output elasticity of industrial energy demand was calculated as 0.8 , whereas the corresponding price elasticity for a price increase was around -0.6 , and a price cut was -0.3 . Lee and Lee [11] used the data for 25 selected OECD countries over 26 years (1978 to 2004) and 
estimated the total energy demand and electricity demand as a function of real output and real price. The estimation results suggested that the demand for total energy is largely driven by strong economic growth and is inelastic to price changes.

Other studies narrowed the scope of the research to investigate sectoral-level energy demand but used time-series data [12-14]. Christodoulakis et al. [12] separated the economic sectors as tradable, less tradable, or public-agricultural to estimate the short- and long-term energy demand elasticities for over 21 years from 1974 to 1994 in Greece. They found that long-term output elasticities (0.76 to $1.95)$ and price elasticities $(-0.19$ to -0.24$)$ were generally larger than the short-term values among the tradable, less tradable, and public-agricultural sector. The estimation results also showed that the long-term output and price elasticities tended to be larger than in the short term, but the demand for energy in the public-agricultural sector was irresponsive to changes in the real prices of energy. Galindo [13] investigated the price elasticity of energy demand in Mexico using a co-integration approach for 37 years from 1965 to 2001, and estimated the energy consumption for each sector (transport, residential, industrial, and agricultural) as a function of output and the own real price. The estimation result showed that the long-term energy demand was largely driven by the output across the sectors, except for the industrial sector where the price variable was statistically significant. The short-term and long-term price elasticities were below -0.5 (short-term estimated price elasticity was about -0.2) in all instances. Liddle [14] estimated the price and the income elasticities of total, industrial, and transport energy consumption and residential and commercial electricity demand of the United States by using the Dynamic Common Correlated Effects Estimator (DCCE) estimator of Chudik and Pesaran [15]. The long-term output elasticities (0.222 to 0.705$)$ and price elasticities $(-0.112$ to -0.280 ) were shown to be generally greater than the corresponding short-term output elasticities (0.177 to 0.290$)$ and price elasticities $(-0.118$ to -0.241$)$.

Other studies used panel data and investigated the sectoral-level energy demand [16-18]. However, these studies either focused on a specific sector or used different classifications within industrial sector (manufacturing and non-manufacturing in general) to estimate the energy demand. Howarth et al. [16] decomposed economic activity into residential, manufacturing, and other sectors to measure their corresponding energy intensity, and examined the trends in primary energy use over 16 years (1973-1988) in five OECD countries: The United States, Norway, Denmark, West Germany, and Japan. They observed declining energy use during the oil-price shocks of 1973 and 1979, followed by steady growth in energy use from the late 1970s onward. Liu [17] measured the energy demand elasticity in the industrial sector separately from that of the residential sector in OECD countries. By applying a difference GMM estimator over the period of 1978 to 1999, they found that electricity, natural gas, and gas oil demand in the residential sector were generally more responsive to price changes than in the industrial sector. In contrast, the energy demand in response to changes in output was less elastic in the residential sector than in the industrial sector. The estimated results suggest that the industrial sector's short- and long-term price elasticities of demand varied, depending on the type of energy products, from -0.167 to 0.043 and -0.516 to 0.589 , respectively. The industrial sector's shortand long-term output elasticities of demand for four energy products (electricity, natural gas, gas oil, and automobile diesel) were estimated in the range of -0.300 to 0.529 and 1.035 to 1.557 , respectively. Narayan et al. [18] estimated the long- and short-term output and price elasticities of residential demand for electricity in the G7 countries. The estimation results showed that the long-term own-price elasticity of electricity demand was in the range of -1.450 to -1.563 , which was approximately 13 times greater than the short-term values. The estimated long-term output elasticities were in the range of 0.245 to 0.312 , which were 1.5 times greater than the short-term values. Medlock III and Soligo [19] showed that the long-term price elasticity of industrial and other sector's energy demand to be -0.27 and the short-term price elasticity to be -0.066 by using panel data from 28 countries over 18 years from 1978 to 1995.

As noted above, the reported magnitude of price elasticities varies with the changing coverage of the sample period, countries, sectors, fuel type, and methodologies. A review paper by 
Labandeira et al. [20] argued that long-term elasticities were generally three times greater than the short-term elasticities.

Table 1 summarizes the selected literature on the output and price elasticities of energy demand. Since the units of analysis from the earlier studies were constrained to either the sectoral or country level, their cross-sectional data points barely exceeded two digits. In contrast, we extended the unit of analysis to include 16 industries for 20 countries, which provided 274 cross-sectional data points to analyze. Although the total number of panels was, by definition, 320, which is a multiplication of 20 countries by 16 industries, after excluding missing observations, the number decreased to 274 .

Table 1. Comparison of output and price elasticity of energy demand in selected literature.

\begin{tabular}{|c|c|c|c|c|c|c|}
\hline \multirow[b]{2}{*}{ Reference } & \multicolumn{3}{|l|}{ Unit of Analysis ${ }^{1}$} & \multirow{2}{*}{ Methodology } & \multirow{2}{*}{ LT Output } & \multirow{2}{*}{ LT Price } \\
\hline & Subject & Country & Time & & & \\
\hline $\begin{array}{l}\text { Bentzen and } \\
\text { Engstead [7] }\end{array}$ & $\begin{array}{l}\text { Total energy demand } \\
\text { (1) }\end{array}$ & Denmark (1) & $\begin{array}{l}1948-1990 \\
(43)\end{array}$ & $\begin{array}{l}\text { Co-integration and } \\
\text { error-correction } \\
\text { methods }\end{array}$ & 1.213 & -0.465 \\
\hline Liu [17] & $\begin{array}{l}\text { Industrial, residential } \\
\text { sector energy demand } \\
\text { (2) }\end{array}$ & $\begin{array}{l}\mathrm{OECD}^{2} \\
(23)\end{array}$ & $\begin{array}{l}1978-1999 \\
(22)\end{array}$ & Difference GMM ${ }^{3}$ & $1.035-1.557$ & $\begin{array}{l}-0.516 \\
\text { to } 0.589\end{array}$ \\
\hline Galindo [13] & $\begin{array}{l}\text { Transport, residential, } \\
\text { industrial, and } \\
\text { agricultural sector } \\
\text { energy demand } \\
\text { (4) }\end{array}$ & $\begin{array}{l}\text { Mexico } \\
\text { (1) }\end{array}$ & $\begin{array}{l}1965-2001 \\
(37)\end{array}$ & $\begin{array}{l}\text { Co-integration } \\
\text { approach }\end{array}$ & 0.96 & $\begin{array}{l}\text { below } \\
-0.5\end{array}$ \\
\hline $\begin{array}{l}\text { Hunt and } \\
\text { Ninomiya [8] }\end{array}$ & $\begin{array}{l}\text { Total energy demand } \\
\text { (1) }\end{array}$ & $\begin{array}{l}\text { Japan } \\
\text { (1) }\end{array}$ & $\begin{array}{l}1887-2001 \\
(115)\end{array}$ & $\begin{array}{l}\text { Autoregressive } \\
\text { Distributive Lag } \\
\text { (ARDL) model }\end{array}$ & 1.06 & -0.2 \\
\hline $\begin{array}{l}\text { Al-Rabbai and } \\
\text { Hunt [9] }\end{array}$ & $\begin{array}{l}\text { National energy } \\
\text { demand } \\
\text { (1) }\end{array}$ & $\begin{array}{l}\text { OECD } \\
(17)\end{array}$ & $\begin{array}{l}1960-2003 \\
(44)\end{array}$ & $\begin{array}{l}\text { Structural time } \\
\text { series (ARDL) }\end{array}$ & 1.5 & -0.4 \\
\hline $\begin{array}{l}\text { Adeyemi and } \\
\text { Hunt [10] }\end{array}$ & $\begin{array}{l}\text { Industrial energy } \\
\text { demand } \\
\text { (1) }\end{array}$ & $\begin{array}{l}\text { OECD } \\
(15)\end{array}$ & $\begin{array}{l}1962-2003 \\
(42)\end{array}$ & $\begin{array}{l}\text { Non-linear least } \\
\text { squares }\end{array}$ & 0.8 & -0.22 \\
\hline $\begin{array}{l}\text { Narayan et al. } \\
\text { [18] }\end{array}$ & $\begin{array}{l}\text { Residential aggregate } \\
\text { energy and electricity } \\
\text { demand } \\
\text { (1) }\end{array}$ & $\begin{array}{l}\text { G7 } \\
(7)\end{array}$ & $\begin{array}{l}1978-2003 \\
(26)\end{array}$ & $\begin{array}{l}\text { Panel unit root and } \\
\text { Panel co-integration } \\
\text { techniques } \\
\text { (Difference GMM) }\end{array}$ & $0.245-0.312$ & $\begin{array}{l}-1.450 \\
\text { to } \\
-1.563\end{array}$ \\
\hline $\begin{array}{l}\text { Cuddington } \\
\text { and Dagher } \\
\text { [21] }\end{array}$ & $\begin{array}{l}\text { Residential electricity } \\
\text { demand } \\
\text { (1) }\end{array}$ & $\begin{array}{l}\text { Minnesota, } \\
\text { USA } \\
\text { (1) }\end{array}$ & $\begin{array}{l}1 / 1998- \\
12 / 2006 \\
(108)\end{array}$ & $\begin{array}{l}\text { Auto Distributed } \\
\text { Lag Model (ADL) }\end{array}$ & -0.39 & -0.60 \\
\hline Liddle [14] & $\begin{array}{l}\text { Total, industrial, } \\
\text { transport energy; } \\
\text { residential, } \\
\text { commercial electricity } \\
\text { demand } \\
\text { (5) }\end{array}$ & $\begin{array}{l}48-50 \text { states, } \\
\text { USA ( } 48-50)\end{array}$ & $\begin{array}{l}1987-2013 \\
(27)\end{array}$ & $\begin{array}{l}\text { Dynamic Common } \\
\text { Correlated Effects } \\
\text { Estimator (DCCE) }\end{array}$ & $0.222-0.705$ & $\begin{array}{l}-0.112 \\
\text { to } \\
-0.280\end{array}$ \\
\hline
\end{tabular}

\footnotetext{
${ }^{1}$ Number in parenthesis indicates the number of data points. ${ }^{2}$ OECD indicates Organization for Economic

Cooperation and Development. ${ }^{3}$ GMM indicates generalized method of moments.
}

\section{Materials and Methods}

\subsection{Model Specification}

Following Espey [22], Espey and Espey [23], Alberini and Filippini [24], and Santos [25], energy demand is expressed as a function of energy price and value-added.

$$
E C_{i j, t}=f\left(P_{i j, t}, V A_{i j, t}\right)
$$

where $E C_{i j, t}, P_{i j, t}$, and $V A_{i j, t}$ represent total final-energy demand, aggregate energy-price index, and value-added, respectively, for industry $j$ of country $i$ in year $t$. 
Aggregate price index is calculated per Equation (2). Earlier studies [9,25-29] used such measures to calculate the price index:

$$
P_{i j, t}=\frac{\sum_{n} P_{i, t}^{n} \times E C_{i j, t}^{n}}{\sum_{n} E C_{i j, t}^{n}}
$$

where $n$ represents the types of energy products.

A static model assumes that energy demand is instantaneously adjusted toward long-term equilibrium when the energy price or industry value-added changes, and that price and value-added are strictly exogenous. However, the static model fails to represent the true dynamics of the technological and institutional characteristics of an energy market. For example, the natural gas supply contracts that typically last for several months to years and sunk cost of current power generation plants may restrain the prompt adjustment of energy demand in response to price and/or output changes. In this case, investigating the long-term price and output elasticities is also necessary to incorporate such effects. Therefore, we incorporated the rigid nature of the energy market into the model and estimated the long-term as well as short-term elasticities.

Measuring long-term elasticity supposes that the actual demand does not coincide with the long-term equilibrium. Liu [17], Alberini and Filippini [24], and the Partial Adjustment Model (PAM) in Cuddington and Dagher [21] considered the difference between the actual and desired energy demand, represented in Equation (3). These studies assume that the actual demand change between two periods $t-1$ and $t$ is only the partial fraction of the difference between the long-term desired energy use at year $t$ and the actual demand at year $t-1$. Consequently, $\lambda$ represents the rate of adjustment between any two time periods toward the long-term equilibrium demand. If $\lambda$ equals 1 , then the desired energy use becomes identical to the actual demand.

$$
E C_{i j, t}-E C_{i j, t-1}=\lambda\left(E C_{i j, t}^{*}-E C_{i j, t-1}\right) .
$$

Using a log-log functional form, the accumulated long-term effects of a price change can be estimated using Equations (4)-(6). For simplification, the "log" notation is omitted for the remainder of this section. The demand equation of Alberini and Filippini [24] was used, expressed in Equation (4), where the desired energy use is a function of energy price and a vector of variables influencing energy demand including output. $\mu_{i j}$ denotes the fixed effect for industry $j$ of country $i$ and $\varepsilon_{i j, t}$ represents idiosyncratic error.

$$
E C_{i j, t}^{*}=\alpha_{0}+\alpha_{1} P_{i j, t}+\alpha_{2} V A_{i j, t}+\mu_{i j}+\varepsilon_{i j, t} .
$$

Inserting Equation (4) into Equation (3), we obtain Equation (5), which includes a previous lagged dependent variable as an independent variable:

$$
\begin{aligned}
E C_{i j, t} & =(1-\lambda) E C_{i j, t-1}+\lambda \alpha_{0}+\lambda \alpha_{1} P_{i j, t}+\lambda \alpha_{2} V A_{i j, t}+\mu_{i j}+\varepsilon_{i j, t} \\
& =\gamma E C_{i j, t-1}+\beta_{0}+\beta_{1} P_{i j, t}+\beta_{2} V A_{i j, t}+\mu_{i j}+\varepsilon_{i j, t}
\end{aligned}
$$

where $\gamma=(1-\lambda), \beta_{0}=\lambda \alpha_{0}, \beta_{1}=\lambda \alpha_{1}$, and $\beta_{2}=\lambda \alpha_{2} . \beta_{1}$ and $\beta_{2}$ indicate the short-term price and output elasticities of the total final consumption for industry $i$ of a country $j$ at time $t$, respectively. Including possible lag length for independent variables was considered. However, the specification results after each estimated model suggested that the residuals are white noise. This led us to believe that the PAM sufficiently captures the possible effect of price and output changes on energy demand.

The marginal effect of price change in year $t$ on energy demand in the subsequent period $s$ is estimated to be:

$$
\frac{\partial E C_{i j, t+s}}{\partial P_{i j, t}}=\gamma^{s} \beta_{1}
$$

The effect of a price change in year $t$ on long-term demand becomes the accumulation of these marginal effects and is calculated by the short-term elasticities divided by $1-\gamma$, as in Equation (6): 


$$
\sum_{s=0}^{\infty} \frac{\partial E C_{i j, t+s}}{\partial P_{i j, t}}=\beta_{1}+\gamma \beta_{1}+\gamma^{2} \beta_{1}+\ldots=\frac{\beta_{1}}{(1-\gamma)} .
$$

In choosing the appropriate econometric estimation techniques, Baltagi [2] expressed concern that the fixed-effect and random-effect model with a lagged dependent variable on the right-hand side was serially correlated with the residuals, which causes the parameter estimates to be inconsistent and biased. As an alternative, Anderson and Hsiao [30] suggested the first difference transformation of Equation (5) given by Equation (7) and using a lagged level of the dependent variable as an instrument to yield consistent estimates of parameters. Difference GMM is used to further investigate additional instruments by exploiting orthogonality conditions between the dependent variable and disturbances [4,31]. System GMM estimation, proposed by Blundell and Bond [5], uses both levels and first differences as instruments in the models, and exploits a full set of orthogonality conditions for both levels and differences to be used as instruments. System GMM was reported to be a more efficient and stable estimator in the presence of a persistent autoregressive process [5]. In this paper, both difference and system GMM estimation were used to identify consistent findings across these estimators. The efficacy of the methodologies was examined given the characteristics of the dataset. Specification tests that evaluated the validity of the instruments and second-order serial correlation were separately conducted for each model.

$$
\Delta E C_{i j, t}=\beta_{1} \Delta P_{i j, t}+\beta_{2} \Delta V A_{i j, t}+\gamma \Delta E C_{i j, t-1}+\Delta \varepsilon_{i j, t} .
$$

Extra instrumental variables are necessary if the explanatory variables, price, and value-added are endogenous with the dependent variable, as cited by Miller and Alberini [32]. The aggregate energy-price index depends on the amount of each energy product that industry consumes and thus is endogenous with energy consumption. Liu [17] reported their estimation results under the assumption that the price was an endogenous variable that was correlated with contemporaneous energy consumption errors. Several previous studies also asserted that value-added and energy demand have bi-directional causality [33-36]. Therefore, price and value-added are assumed to be endogenous with energy consumption, so corresponding instruments to estimate the elasticities are used.

\subsection{Data Description}

The data used in this paper were collected from sources listed in Table 2. Data for industrial value-added were obtained from OECD Structural Analysis (STAN) database [37]. This database contains annual measures of output for International Standard Industrial Classification (ISIC) Revision 4 activities expressed in national currency. To convert national currency into United States dollar, World Development Indicator provided by World Bank was used [38]. Data for energy demand and energy price were obtained from the Energy Statistics and Balances 2015 and from Energy Prices and Taxes 2017, both provided by the IEA [39-41]. IEA Energy Statistics and Balances includes estimates of the energy flow from production to total final consumption for each energy product, including coal, oil, natural gas, and electricity. The energy consuming sectors were classified into industrial sector, transportation sector, and others. From industrial and other sectors, 16 industries were defined and were assigned industry code of ISIC Revision 4.

Matched by the industry code of the ISIC Revision 4 for each of those 16 industries, the industrial output data was combined with industrial energy consumption and energy-price data. The full dataset consists of 16 industries of 20 OECD countries over 1978 to 2013 and includes annual data of total final-energy consumption, total energy-price index, and value-added, as shown in Table 3.

We separately measured the energy demand elasticity of both the price and output by dividing the industries into energy-intensive and less energy-intensive groups. Despite the controversial nature of their definition and the scope, previous studies have identified five industries that consume more energy than the average of all industries as energy-intensive industries: iron and steel, non-ferrous 
metals, non-metallic minerals, chemical, and pulp and paper [42-44]. This classification was adopted, and the dataset confirmed that their energy costs did account for a relatively higher proportion of total input costs when compared to other industries that were classified as less energy-intensive. Table 4 reports the list of industries in the two groups.

Table 2. Data sources.

\begin{tabular}{cc}
\hline Variables & Data Source \\
\hline Energy Consumption & IEA Energy Statistics and Balances \\
Value-added & OECD Structural Analysis (STAN) database \\
Energy-Price Index & IEA Energy Prices and Taxes Statistics \\
\hline
\end{tabular}

Table 3. Data description.

\begin{tabular}{|c|c|}
\hline Data Component & Content \\
\hline Period (36) & 1978-2013 \\
\hline Country (20) & $\begin{array}{l}\text { Austria, Belgium, Canada, Czech Republic, Denmark, Finland, France, Germany, } \\
\text { Hungary, Italy, Japan, Korea, Netherlands, Poland, Portugal, Slovak Republic, } \\
\text { Switzerland, Turkey, United Kingdom, United States }\end{array}$ \\
\hline $\begin{array}{l}\text { Industry Classification } \\
\qquad(16)\end{array}$ & $\begin{array}{l}\text { Agriculture/forestry, Chemical and petrochemical, Commercial and public } \\
\text { services, Construction, Fishing, Food and tobacco, Iron and steel, Machinery, } \\
\text { Mining and quarrying, Less-ferrous metals, Less-metallic minerals, Non-specified } \\
\text { (industry), Paper, pulp and printing, Textile and leather, Transport equipment, } \\
\text { Wood and wood products }\end{array}$ \\
\hline
\end{tabular}

Note: Numbers in parenthesis indicate the number of data points.

Table 4. Industry classification by energy intensity.

\begin{tabular}{cl}
\hline Energy Intensity & \multicolumn{1}{c}{ Industry } \\
\hline Energy-Intensive & $\begin{array}{l}\text { Non-ferrous metals; Iron and steel; Chemical and petrochemical; Non-metallic } \\
\text { minerals; and Paper, pulp, and printing }\end{array}$ \\
\hline Less energy-intensive & $\begin{array}{l}\text { Fishing, Mining and quarrying, Commercial and public services, Non-specified } \\
\text { (industry), Wood and wood products, Agriculture/forestry, Transport equipment, } \\
\text { Textile and leather, Construction, Machinery, and Food and Tobacco }\end{array}$ \\
\hline
\end{tabular}

Table 5 summarizes the descriptive statistics of the log-transformed variables used in our empirical analysis. The sample contain 3856 observations, with each industry having an energy consumption of 13.95 and value-added of 6.56 on average. The standard deviations for energy consumption and value-added were 1.73 and 0.42 , respectively. The price index was used as a proxy for price corresponding to the total final-energy consumption for each industry of a country. Price index was defined as a weighted average of coal, natural gas, electricity, and oil price by its consumption for each industry of a country. On average, each industry was assigned energy price of 23.32, which is the log-transformed mean of energy price expressed in constant United States dollar. Value-added and the energy-price index were calculated in real value United States dollar terms using 2010 as a base year.

Table 5. Descriptive statistics (log transformation).

\begin{tabular}{cccccc}
\hline Variable & Number of Observations & Mean & Standard Deviation & Minimum & Maximum \\
\hline Energy Consumption $^{1}$ & 3856 & 13.95 & 1.73 & 6.91 & 19.25 \\
Value-added $^{2}$ & 3856 & 6.56 & 0.42 & 5.24 & 8 \\
Energy-Price Index $^{3}$ & 3856 & 23.32 & 1.79 & 17.06 & 28.24 \\
\hline \multicolumn{2}{c}{${ }^{1}$ kilo tone of oil equivalent (kTOE), $^{2}$ million United States dollars, ${ }^{3}$ United States dollars per TOE. }
\end{tabular}




\section{Estimation Results}

The price and output elasticities between the energy-intensive and less energy-intensive group were compared across four models from Model 1 to Model 4 (Table 6). Models 1 and 3 estimated the basic equation; the results from Equation (7) using difference GMM and system GMM are represented by Models 1 and 3, respectively. Time dummies were added to Models 2 and 4 to capture technological innovation or other time-specific factors that are not accurately modeled by either of the independent variables. Models 1 and 2 reported the estimation results by difference GMM estimation, whereas Models 3 and 4 were the results obtained by applying system GMM estimation. Using Stata Statistical Software: Release 15 (StataCorp LLC, College Station, TX, USA) [45], the lag structure of instruments was adjusted for each model to pass the necessary post-estimation tests.

Table 6. Model descriptions.

\begin{tabular}{ccccc}
\hline & Model 1 & Model 2 & Model 3 & Model 4 \\
\hline Technique & Difference GMM & Difference GMM & System GMM & System GMM \\
Year FE & NO & YES & NO & YES \\
Country FE & NO & NO & NO & NO \\
\hline
\end{tabular}

Adding country dummies to control for potential heterogeneity across countries was considered. However, introducing country dummies either generated too many regressors or resulted in instrument proliferation with abnormally high parameter estimates of the lagged dependent variable. This could potentially cause bias and yield unreliable results as pointed out by Roodman [46,47] and Sargan [48]. We considered that Models 2 and 4 sufficiently captured heterogeneity across industries and countries. As each industry of a country under these two models was assigned a different set of time dummies as their instruments, this could potentially minimize heterogeneity concerns. Potential heterogeneity can also be controlled by heterogeneous panel data estimates [49].

The following results were expected: (1) energy demand of an industry in reaction to price and output changes is more elastic in the long term than in the short term for both energy-intensive industries and less energy-intensive industries, (2) price elasticity of energy demand is lower in energy-intensive industries than in less energy-intensive industries, and (3) the output elasticity of energy demand is higher in energy-intensive industries than in less energy-intensive industries.

To verify the expectation, an estimation using the entire dataset, including both the energy-intensive and less energy-intensive group, was initially performed. As reported in Tables 7 and 8, the short-term price elasticities of the total final-energy consumption ranged from -0.010 to -0.151 . The parameter estimates for price index were consistently less than one, implying that the short-term energy demand is inelastic to energy price. This finding is similar to that reported by Medlock III and Soligo [19], who reported the short-term price elasticities of total final-energy consumption as -0.0667 .

The long-term price elasticity estimates ranged from -0.047 to -0.234 , as each model evaluates the long-term effect of each independent variable on energy demand differently from the others. Statistically significant parameters of the lagged dependent variable suggest that the short-term and long-term elasticities were different. The estimation results were consistent with earlier studies. Medlock III and Soligo [19] reported that the long-term price elasticities of the total final-energy consumption of 28 countries over similar timeframes to be -0.27 . Lee and Lee [11] estimated the long-term price elasticities of total energy consumption in 25 OECD countries over similar timeframes as -0.2 . 
Table 7. Estimation results (full dataset).

\begin{tabular}{ccccc}
\hline \multirow{2}{*}{ Variable } & Model 1 & Model 2 & Model 3 & Model 4 \\
\cline { 2 - 5 } & DGMM & DGMM & SGMM & SGMM \\
\cline { 2 - 5 } & TFEC & TFEC & TFEC & TFEC \\
\hline TFEC $=\mathrm{L}$ & $0.355^{* * *}$ & $0.504^{* * *}$ & $0.746^{* * *}$ & $0.789^{* * *}$ \\
& $(0.000)$ & $(0.000)$ & $(0.000)$ & $(0.000)$ \\
\hline Price Index & $-0.151^{* * *}$ & $-0.094^{* * *}$ & -0.037 & -0.010 \\
& $(0.000)$ & $(-0.004)$ & $(-0.301)$ & $(-0.793)$ \\
\hline Value-added & $0.514^{* * *}$ & $0.159^{* * *}$ & $0.109^{*}$ & $0.185^{* *}$ \\
& $(0.000)$ & $(-0.017)$ & $(-0.063)$ & $(-0.029)$ \\
\hline Observations & 3307 & 3307 & 3627 & 3627 \\
Number of id & 257 & 257 & 258 & 258 \\
Year FE & No & Yes & No & Yes \\
Country FE & No & No & No & No \\
\hline
\end{tabular}

Note: $p$-vales are in parentheses. ***,**, and * indicate that the estimated parameters are significant at the $1 \%, 5 \%$, and $10 \%$ confidence levels, respectively. TFEC denotes total final-energy consumption. TFEC $=\mathrm{L}$ indicates the lagged total final-energy consumption. DGMM and SGMM indicate difference and system generalized method of moment, respectively. FE denotes fixed effect.

Table 8. Short-term and long-term elasticity estimates.

\begin{tabular}{ccccc}
\hline Variable & Model 1 & Model 2 & Model 3 & Model 4 \\
\hline ST Price Index & -0.151 & -0.094 & -0.037 & -0.010 \\
LT Price Index & -0.234 & -0.190 & -0.146 & -0.047 \\
ST Value-added & 0.514 & 0.159 & 0.109 & 0.185 \\
LT Value-added & 0.797 & 0.321 & 0.429 & 0.877 \\
\hline
\end{tabular}

Note: ST and LT indicate short term and long term, respectively.

Next, the elasticities of the energy-intensive group were assessed to determine if different models yielded consistent results. As reported in Tables 9 and 10, the short-term price elasticities of the total final-energy consumption for this group presented limited consistency in terms of statistical significance. The magnitudes of the parameters varied across models, ranging from -0.029 to -0.200 , but remained consistently below -0.2 . The long-term price elasticities ranged from -0.128 to -0.529 and stayed below -0.53 . Model 1 reported the greatest long-term price elasticity of energy demand, with -0.529 .

Table 9. Estimation results (energy-intensive group).

\begin{tabular}{ccccc}
\hline \multirow{2}{*}{ Variable } & Model 1 & Model 2 & Model 3 & Model 4 \\
\cline { 2 - 5 } & DGMM & DGMM & SGMM & SGMM \\
\cline { 2 - 5 } & TFEC & TFEC & TFEC & TFEC \\
\hline TFEC $=\mathrm{L}$ & $0.622^{* * *}$ & $0.535^{* * *}$ & $0.626^{* * *}$ & $0.774^{* * *}$ \\
& $(0.000)$ & $(0.002)$ & $(0.000)$ & $(0.000)$ \\
\hline Price Index & $-0.200^{* *}$ & -0.096 & $-0.126^{*}$ & -0.029 \\
& $(0.014)$ & $(0.334)$ & $(0.070)$ & $(0.850)$ \\
\hline Value-added & $0.319^{* * *}$ & $0.418^{* * *}$ & $0.402^{* * *}$ & $0.283^{* * *}$ \\
& $(0.003)$ & $(0.000)$ & $(0.009)$ & $(0.010)$ \\
\hline Observations & 1146 & 1146 & 1248 & 1248 \\
Number of id & 80 & 80 & 81 & 81 \\
Year FE & NO & YES & NO & YES \\
Country FE & NO & NO & NO & NO \\
\hline
\end{tabular}

Note: $p$-vales are in parentheses. ${ }^{* *}, * *$, and ${ }^{*}$ indicate that the estimated parameters are significant at the $1 \%, 5 \%$ and $10 \%$ confidence levels, respectively. 
Table 10. Short-term and long-term elasticity estimates (energy-intensive group).

\begin{tabular}{ccccc}
\hline Variable & Model 1 & Model 2 & Model 3 & Model 4 \\
\hline ST Price Index & -0.200 & -0.096 & -0.126 & -0.029 \\
LT Price Index & -0.529 & -0.206 & -0.337 & -0.128 \\
ST Value-added & 0.319 & 0.418 & 0.402 & 0.283 \\
LT Value-added & 0.844 & 0.899 & 1.075 & 1.230 \\
\hline
\end{tabular}

Contrary to price elasticities, the short-term output elasticities of the total final-energy consumption for this group were statistically significant in all circumstances. The magnitudes of output elasticities were greater than the corresponding price elasticities for both the short and long term. This implies that energy use in these industries is more likely to be driven by output changes and not price fluctuations. The results varied across models, ranging from 0.283 to 0.418 , but overall were consistently below 0.5 . The long-term output elasticities ranged from 0.844 to 1.230 and stayed below 1.3. Model 4 reported the greatest long-term output elasticity of energy demand, with 1.230.

Finally, the elasticities of the less energy-intensive group were examined to determine if different models yielded consistent results. As reported in Tables 11 and 12, the parameter estimates for energy price were statistically significant in all instances. The results varied across the models, ranging from -0.078 to -0.165 but remaining consistently below -0.2 . The long-term price elasticities ranged from -0.210 to -0.594 and stayed below -0.60 . Model 3 produced the highest long-term price elasticity at -0.594 . Less energy-intensive industries showed a higher responsiveness to changes in price than the intensive industries for both short and long term with high consistency.

Table 11. Estimation results (less energy-intensive group).

\begin{tabular}{ccccc}
\hline \multirow{2}{*}{ Variable } & Model 1 & Model 2 & Model 3 & Model 4 \\
\cline { 2 - 5 } & DGMM & DGMM & SGMM & SGMM \\
\cline { 2 - 5 } & TFEC & TFEC & TFEC & TFEC \\
\hline TFEC $=\mathrm{L}$ & $0.589^{* * *}$ & $0.623^{* * *}$ & $0.722^{* * * *}$ & $0.655^{* * *}$ \\
& $(0.000)$ & $(0.003)$ & $(0.000)$ & $(0.000)$ \\
\hline Price Index & $-0.123^{* * *}$ & $-0.079^{*}$ & $-0.165^{*}$ & -0.078 \\
& $(0.001)$ & $(0.096)$ & $(0.074)$ & $(0.348)$ \\
\hline Value-added & 0.082 & 0.152 & $0.186^{* * *}$ & $0.182^{* *}$ \\
& $(0.458)$ & $(0.131)$ & $(0.008)$ & $(0.013)$ \\
\hline Observations & 2161 & 2161 & 2379 & 2379 \\
Number of id & 177 & 177 & 177 & 177 \\
Year FE & NO & YES & NO & YES \\
Country FE & NO & NO & NO & NO
\end{tabular}

Note: $p$-vales are in parentheses. ${ }^{* * *},{ }^{* *}$, and ${ }^{*}$ indicate that the estimated parameters are significant at the $1 \%, 5 \%$, and $10 \%$ confidence levels, respectively.

Table 12. Short-term and long-term elasticity estimates (less energy-intensive group).

\begin{tabular}{ccccc}
\hline Variable & Model 1 & Model 2 & Model 3 & Model 4 \\
\hline ST Price Index & -0.123 & -0.079 & -0.165 & -0.078 \\
LT Price Index & -0.299 & -0.210 & -0.594 & -0.226 \\
ST Value-added & 0.082 & 0.152 & 0.186 & 0.182 \\
LT Value-added & 0.200 & 0.403 & 0.669 & 0.481 \\
\hline
\end{tabular}

Their output elasticities, in contrast to energy-intensive industries, showed limited consistency in terms of statistical significance. Consistently higher magnitudes of elasticities in output than price for this industry group were not observed. The results varied across models, ranging from 0.082 to 0.186 , but were consistently below 0.2 . The long-term output elasticities ranged from 0.200 to 
0.669 and stayed below 0.7. Model 3 reported the greatest long-term output elasticity of energy demand with 0.669 . Comparing the magnitudes of output elasticities between the energy-intensive and less energy-intensive groups, the less energy-intensive group generally received smaller parameter estimates. Whereas less energy-intensive industries were more responsive to energy price than energy-intensive industries, they were less responsive to output. Detailed estimation results for each model are reported separately in supplementary tables in Appendix A from Tables A1-A8.

In summary, our findings were: (1) the less energy-intensive industries were relatively more price elastic than the intensive group, (2) the energy-intensive industries were relatively more output elastic than the less-intensive industries, and (3) the energy demand of an industry in reaction to price and output changes was more elastic in the long term than in the short term, irrespective of industry classification.

The results using system GMM indicated greater multipliers than those produced using difference GMM. Blundell and Bond [6] addressed this issue by demonstrating how using difference GMM could downward bias the estimated results when instruments were weak. They stated that such bias could be significantly mitigated once additional moment conditions, valid under stationarity restrictions, were incorporated. As the data presented stationarity, this led us to think that the estimation results under system GMM were less biased and more reliable compared to those under difference GMM. Still, the variations across different models were not significantly different from one another.

\section{Discussion and Conclusions}

The precise measurement of the price elasticity of energy demand would assist in devising an effective price policy. Many of the earlier studies aggregated energy consumption at the country level or sectoral level, which could provide inaccurate measurement of price elasticities, especially at the industry level. Considering each industry's distinctive energy consumption patterns, research into the identification of such differences could provide meaningful insights to policy makers.

We measured the elasticities in more detail by analyzing the sub-sectoral or industry-level data of OECD countries for the short and long term using a dynamic econometric model. Using the historical energy consumption data of 20 OECD countries over 36 years, 16 industries were classified into two groups by their intensity of energy consumption. Then, the short- and long-term elasticities were estimated using the difference and system GMM estimations. Finally, the elasticities were compared between these two groups.

We found that energy-intensive industries consistently adjusted less of their energy consumption to price changes than the less energy-intensive industries. The energy-intensive group is not thought to have less incentive to decrease energy use than the less energy-intensive group, considering the share of energy cost is greater for the energy-intensive industries. We think that (1) energy-intensive industries cannot afford to reduce energy consumption because these industries require energy as an essential input for their productions, and (2) their alternatives to replace energy with other inputs, such as labor or capital, are rather ineffective or not viable. For example, steel production, by default, requires large amounts of energy for heating, melting, and combusting, none of which either labor or capital can replace. In such situations, these industries have no choice but to absorb almost the full effect of energy-price changes.

We found that energy-intensive industries were more elastic to output changes than less energy-intensive industries. This implies that their energy consumption and production were more intimately intertwined than in the other group. Finally, the energy demand response with changes in both energy prices and output appear to be more elastic in the long term than in the short term for both groups.

These findings could provide a useful reference for policy makers to deploy separate energy policies for different industries aiming to produce different temporal effects. For example, our findings evidence that the price regulation for energy-intensive industries may not be as effective as for less energy-intensive industries. In such cases, different policy measures are preferable; facilitating 
technological innovation would improve energy efficiency. Industry-wide structural change (i.e., increased proportion of the service sector out of all industries) could be an alternative to a moderate energy consumption growth rate, provided that consumers increasingly demand products that are less energy-intensive.

As future research, other factors such as technology variable as pointed out by Chang [50] could be included to estimate energy demand function. The level of technological innovation of a particular industry could decrease the energy consumption of that industry producing the same amount of output. With the availability of more granular data, estimating the elasticities separately by fuel type instead of their aggregation would provide a more detailed analysis of the price and output elasticities of energy demand.

Author Contributions: Conceptualization, B.C., S.J.K. and T.Y.J.; Data curation, B.C.; Formal analysis, B.C., S.J.K. and T.Y.J.; Investigation, B.C.; Methodology, B.C., S.J.K. and T.Y.J.; Project administration, S.J.K. and T.Y.J.; Resources, S.J.K.; Software, B.C.; Supervision, S.J.K. and T.Y.J.; Validation, S.J.K. and T.Y.J.; Visualization, B.C.; Writing—original draft, B.C.; Writing—-review \& editing, S.J.K. and T.Y.J.

Funding: This research received no external funding.

Conflicts of Interest: The authors declare no conflict of interest.

\section{Appendix A}

Below tables are the estimation results for each Model cited in the main text.

Table A1. Difference GMM estimation results (Model 1).

\begin{tabular}{cccc}
\hline \multirow{2}{*}{ Variable } & $\mathbf{( 1 )}$ & $\mathbf{( 2 )}$ & $\mathbf{( 3 )}$ \\
\cline { 2 - 4 } & All & Intensive & Less-Intensive \\
\hline L.TFEC & $0.355^{* * *}$ & $0.622^{* * *}$ & $0.589 * * *$ \\
& $(0.000)$ & $(0.000)$ & $(0.000)$ \\
\hline Price Index & $-0.151^{* * * *}$ & $-0.200^{* * *}$ & $-0.123^{* * *}$ \\
& $(0.000)$ & $(0.014)$ & $(0.001)$ \\
\hline Value-added & $0.514^{* * *}$ & $0.319^{* * *}$ & 0.082 \\
& $(0.000)$ & $(0.003)$ & $(0.458)$ \\
\hline Number of observations & 3307.000 & 1146.000 & 2161.000 \\
Number of id & 257.000 & 80.000 & 177.000 \\
Number of instruments & 63.000 & 63.000 & 102.000 \\
AR(1) & -3.065 & -2.952 & -3.475 \\
AR(1) $p$-value & 0.002 & 0.003 & 0.001 \\
AR(2) & 0.500 & -1.240 & 0.921 \\
AR(2) $p$-value & 0.617 & 0.215 & 0.357 \\
Hansen $p$-value & 0.109 & 0.965 & 0.420 \\
\hline
\end{tabular}

Notes: The $p$-vales are in parentheses. ${ }^{* * *}, * *$, and ${ }^{*}$ indicate that the estimated parameters are significant at $1 \%, 5 \%$ and $10 \%$ confidence level, respectively. TFEC denotes total final-energy consumption. L.TFEC indicates the lagged total final-energy consumption. AR(1) indicates a first-order autoregressive process. AR(2) indicates a second-order autoregressive process. Hansen represents Hansen test.

Table A2. Short-term and long-term elasticity estimates (Model 1).

\begin{tabular}{cccc}
\hline Variable & $\mathbf{( 1 )}$ & $\mathbf{( 2 )}$ & $\mathbf{( 3 )}$ \\
\cline { 2 - 4 } & All & Intensive & Less-Intensive \\
\hline ST Price Index & -0.151 & -0.200 & -0.123 \\
LT Price Index & -0.234 & -0.529 & -0.299 \\
ST Value-added & 0.514 & 0.319 & 0.082 \\
LT Value-added & 0.797 & 0.844 & 0.200 \\
\hline
\end{tabular}

Notes: ST and LT indicate short-term and long-term, respectively. 
Table A3. Difference GMM estimation results (Model 2).

\begin{tabular}{|c|c|c|c|}
\hline & (4) & (5) & (6) \\
\hline Variable & All & Intensive & Less-Intensive \\
\hline L.TFEC & $\begin{array}{c}0.504^{* * *} \\
(0.000)\end{array}$ & $\begin{array}{c}0.535^{* * *} \\
(0.002)\end{array}$ & $\begin{array}{c}0.623 * * * \\
(0.003)\end{array}$ \\
\hline Price Index & $\begin{array}{c}-0.094^{* * *} \\
(0.004)\end{array}$ & $\begin{array}{l}-0.096 \\
(0.334)\end{array}$ & $\begin{array}{c}-0.079 * \\
(0.096)\end{array}$ \\
\hline Value-added & $\begin{array}{c}0.159 * * \\
(0.017)\end{array}$ & $\begin{array}{c}0.418^{* * *} \\
(0.000)\end{array}$ & $\begin{array}{c}0.152 \\
(0.131)\end{array}$ \\
\hline Year1984-1989 & $\begin{array}{l}-0.014 \\
(0.198)\end{array}$ & $\begin{array}{c}0.036 \\
(0.177)\end{array}$ & $\begin{array}{l}0.031 \text { * } \\
(0.087)\end{array}$ \\
\hline Year1990-1995 & $\begin{array}{l}-0.001 \\
(0.941)\end{array}$ & $\begin{array}{c}0.039 \\
(0.296)\end{array}$ & $\begin{array}{c}0.054 * * \\
(0.024)\end{array}$ \\
\hline Year1996-2001 & $\begin{array}{l}-0.008 \\
(0.766)\end{array}$ & $\begin{array}{l}-0.019 \\
(0.704)\end{array}$ & $\begin{array}{c}0.078 * * \\
(0.023)\end{array}$ \\
\hline Year2002-2007 & $\begin{array}{c}-0.046^{*} \\
(0.077)\end{array}$ & $\begin{array}{l}-0.056 \\
(0.260)\end{array}$ & $\begin{array}{c}0.040 \\
(0.252)\end{array}$ \\
\hline Year2008-2013 & $\begin{array}{c}-0.073 \text { ** } \\
(0.016)\end{array}$ & $\begin{array}{l}-0.035 \\
(0.627)\end{array}$ & $\begin{array}{c}0.016 \\
(0.651)\end{array}$ \\
\hline Number of observations & 3307.000 & 1146.000 & 2161.000 \\
\hline Number of id & 257.000 & 80.000 & 177.000 \\
\hline Number of instruments & 206.000 & 53.000 & 95.000 \\
\hline $\mathrm{AR}(1)$ & -3.834 & -2.410 & -2.512 \\
\hline $\operatorname{AR}(1) p$-value & 0.000 & 0.016 & 0.012 \\
\hline $\mathrm{AR}(2)$ & 0.753 & -1.622 & 0.917 \\
\hline $\operatorname{AR}(2) p$-value & 0.451 & 0.105 & 0.359 \\
\hline Hansen $p$-value & 0.490 & 0.901 & 0.225 \\
\hline
\end{tabular}

Notes: The $p$-vales are in parentheses. ${ }^{* * *},{ }^{* *}$, and ${ }^{*}$ indicate that the estimated parameters are significant at $1 \%, 5 \%$ and $10 \%$ confidence level, respectively.

Table A4. Short-term and long-term elasticity estimates (Model 2).

\begin{tabular}{cccc}
\hline \multirow{2}{*}{ Variable } & $\mathbf{( 4 )}$ & $\mathbf{( 5 )}$ & $\mathbf{( 6 )}$ \\
\cline { 2 - 4 } & All & Intensive & Less-Intensive \\
\hline ST Price Index & -0.094 & -0.096 & -0.079 \\
LT Price Index & -0.190 & -0.206 & -0.210 \\
ST Value-added & 0.159 & 0.418 & 0.152 \\
LT Value-added & 0.321 & 0.899 & 0.403 \\
\hline
\end{tabular}

Table A5. System GMM estimation results (Model 3).

\begin{tabular}{cccc}
\hline & $\mathbf{( 7 )}$ & $\mathbf{( 8 )}$ & $\mathbf{( 9 )}$ \\
\cline { 2 - 4 } Variable & All & Intensive & Less-Intensive \\
\hline L.TFEC & $0.746^{* * * *}$ & $0.626^{* * *}$ & $0.722^{* * *}$ \\
& $(0.000)$ & $(0.000)$ & $(0.000)$ \\
\hline Price Index & -0.037 & $-0.126^{*}$ & $-0.165^{*}$ \\
& $(0.301)$ & $(0.070)$ & $(0.074)$ \\
\hline Value-added & $0.109^{*}$ & $0.402^{* * *}$ & $0.186^{* * *}$ \\
& $(0.063)$ & $(0.009)$ & $(0.008)$ \\
\hline Constant & 1.248 & -2.903 & 0.498 \\
& $(0.515)$ & $(0.269)$ & $(0.727)$ \\
\hline Number of observations & 3627.000 & 1248.000 & 2379.000 \\
\hline
\end{tabular}


Table A5. Cont.

\begin{tabular}{cccc}
\hline & $\mathbf{( 7 )}$ & $\mathbf{( 8 )}$ & $\mathbf{( 9 )}$ \\
\cline { 2 - 4 } Variable & All & Intensive & Less-Intensive \\
\hline Number of id & 258.000 & 81.000 & 177.000 \\
Number of instruments & 22.000 & 28.000 & 16.000 \\
AR(1) & -3.462 & -2.922 & -3.723 \\
AR(1) $p$-value & 0.001 & 0.003 & 0.000 \\
AR(2) & 0.813 & -1.331 & 0.999 \\
AR(2) $p$-value & 0.416 & 0.183 & 0.318 \\
Hansen $p$-value & 0.180 & 0.614 & 0.143 \\
\hline
\end{tabular}

Notes: The $p$-vales are in parentheses. ${ }^{* * *}, * *$ and ${ }^{*}$ indicate that the estimated parameters are significant at $1 \%, 5 \%$ and $10 \%$ confidence level, respectively.

Table A6. Short-term and long-term elasticity estimates (Model 3).

\begin{tabular}{cccc}
\hline Variable & $\mathbf{( 7 )}$ & $\mathbf{( 8 )}$ & $\mathbf{( 9 )}$ \\
\cline { 2 - 4 } & All & Intensive & Less-Intensive \\
\hline ST Price Index & -0.037 & -0.126 & -0.165 \\
LT Price Index & -0.146 & -0.337 & -0.594 \\
ST Value-added & 0.109 & 0.402 & 0.186 \\
LT Value-added & 0.429 & 1.075 & 0.669 \\
\hline
\end{tabular}

Table A7. System GMM estimation results (Model 4).

\begin{tabular}{|c|c|c|c|}
\hline \multirow{2}{*}{ Variable } & (10) & (11) & (12) \\
\hline & All & Intensive & Less-Intensive \\
\hline L.TFEC & $\begin{array}{c}0.789 * * * \\
(0.000)\end{array}$ & $\begin{array}{c}0.774^{* * *} \\
(0.000)\end{array}$ & $\begin{array}{c}0.655^{* * *} \\
(0.000)\end{array}$ \\
\hline Price Index & $\begin{array}{l}-0.010 \\
(0.793)\end{array}$ & $\begin{array}{l}-0.029 \\
(0.850)\end{array}$ & $\begin{array}{l}-0.078 \\
(0.348)\end{array}$ \\
\hline Value-added & $\begin{array}{c}0.185^{* *} \\
(0.029)\end{array}$ & $\begin{array}{c}0.283^{* * *} \\
(0.010)\end{array}$ & $\begin{array}{c}0.182^{* *} \\
(0.013)\end{array}$ \\
\hline Year1984-1989 & $\begin{array}{c}0.053^{* * *} \\
(0.001)\end{array}$ & $\begin{array}{c}0.059 * * \\
(0.032)\end{array}$ & $\begin{array}{c}-0.038 * \\
(0.099)\end{array}$ \\
\hline Year1990-1995 & $\begin{array}{c}0.053^{* *} \\
(0.025)\end{array}$ & $\begin{array}{c}0.058 \\
(0.129)\end{array}$ & $\begin{array}{l}-0.017 \\
(0.636)\end{array}$ \\
\hline Year1996-2001 & $\begin{array}{c}0.043 \\
(0.106)\end{array}$ & $\begin{array}{l}-0.027 \\
(0.555)\end{array}$ & $\begin{array}{c}0.006 \\
(0.857)\end{array}$ \\
\hline Year2002-2007 & $\begin{array}{c}0.019 \\
(0.525)\end{array}$ & $\begin{array}{l}-0.063 \\
(0.198)\end{array}$ & $\begin{array}{l}-0.028 \\
(0.455)\end{array}$ \\
\hline Year2008-2013 & $\begin{array}{c}0.016 \\
(0.610)\end{array}$ & $\begin{array}{l}-0.052 \\
(0.445)\end{array}$ & $\begin{array}{l}-0.036 \\
(0.312)\end{array}$ \\
\hline Constant & $\begin{array}{l}-1.335 \\
(0.286)\end{array}$ & $\begin{array}{l}-2.973 \\
(0.213)\end{array}$ & $\begin{array}{c}0.954 \\
(0.629)\end{array}$ \\
\hline Number of observations & 3627.000 & 1248.000 & 2379.000 \\
\hline Number of id & 258.000 & 81.000 & 177.000 \\
\hline Number of instruments & 27.000 & 12.000 & 111.000 \\
\hline $\mathrm{AR}(1)$ & -3.369 & -2.690 & -3.651 \\
\hline $\operatorname{AR}(1) p$-value & 0.001 & 0.007 & 0.000 \\
\hline $\mathrm{AR}(2)$ & 0.799 & -1.357 & 0.973 \\
\hline $\operatorname{AR}(2) p$-value & 0.424 & 0.175 & 0.330 \\
\hline Hansen $p$-value & 0.604 & 0.963 & 0.159 \\
\hline
\end{tabular}

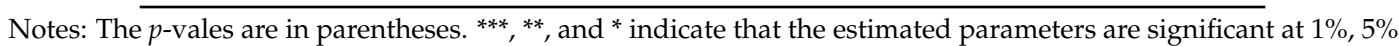
and $10 \%$ confidence level, respectively. 
Table A8. Short-term and long-term elasticity estimates (Model 4).

\begin{tabular}{cccc}
\hline Variable & $\mathbf{( 1 0 )}$ & $\mathbf{( 1 1 )}$ & $\mathbf{( 1 2 )}$ \\
\cline { 2 - 4 } & All & Intensive & Less-Intensive \\
\hline ST Price Index & -0.010 & -0.029 & -0.078 \\
LT Price Index & -0.047 & -0.128 & -0.226 \\
ST Value-added & 0.185 & 0.283 & 0.182 \\
LT Value-added & 0.877 & 1.230 & 0.481 \\
\hline
\end{tabular}

\section{References}

1. International Energy Agency. Key World Energy Statistics of 2017; IEA Publications: Paris, France, $2017 ;$ p. 49.

2. Baltagi, B.H. Econometric Analysis of Panel Data, 3rd ed.; John Wiley \& Sons, Ltd.: New York, NY, USA, 2005; pp. 135-160.

3. Wooldridge, J.M. Introductory Econometrics: A Modern Approach, 5th ed.; South-Western Cengage Learning: Mason, OH, USA, 2012; pp. 10-11.

4. Arellano, M.; Bond, S. Some Tests of Specification for Panel Data: Monte Carlo Evidence and an Application to Employment Equation. Rev. Econ. Stud. 1991, 58, 277-297. [CrossRef]

5. Blundell, R.; Bond, S. Initial Conditions and Moment Restrictions in Dynamic Panel Data Models. J. Econ. 1998, 87, 115-143. [CrossRef]

6. Blundell, R.; Bond, S. GMM Estimation with Persistent Panel Data: An Application to Production Functions. Econ. Rev. 2000, 19, 321-340. [CrossRef]

7. Bentzen, J.; Engsted, T. Expectations, Adjustment Costs, and Energy Demand. Resour. Energy Econ. 1993, 15, 371-385.

8. Hunt, L.C.; Ninomiya, Y. Primary Energy Demand in Japan: An Empirical Analysis of Long-term Trends and Future $\mathrm{CO}_{2}$ emissions. Energy Policy 2005, 33, 1409-1424. [CrossRef]

9. Al-Rabbaie, A.; Hunt, L.C. OECD Energy Demand: Modelling Underlying Energy Demand Trends Using the Structural Time Series Model; Surrey Energy Econ Discussion Paper Series 114; University of Surrey: Guildford, UK, 2006; pp. 1-35.

10. Adeyemi, O.I.; Hunt, L.C. Modeling OECD Industrial Energy Demand: Asymmetric Price Responses and Energy-saving Technical Change. Energy Econ. 2007, 29, 693-709. [CrossRef]

11. Lee, C.C.; Lee, J.D. A Panel Data Analysis of the Demand for Total Energy and Electricity in OECD Countries. Energy J. 2010, 31, 1-23. [CrossRef]

12. Christodoulakis, N.M.; Kalyvitis, S.C.; Lalas, D.P.; Pesmajoglou, S. Forecasting Energy Consumption and Energy Related $\mathrm{CO}_{2}$ Emissions in Greece: An Evaluation of the Consequences of the Community Support Framework II and Natural Gas Penetration. Energy Econ. 2000, 22, 395-422. [CrossRef]

13. Galindo, L.M. Short- and Long-run Demand for Energy in Mexico: A Cointegration Approach. Energy Policy 2005, 33, 1179-1185. [CrossRef]

14. Liddle, B. Accounting for Nonlinearity, Asymmetry, Heterogeneity, and Cross-sectional Dependence in Energy Modeling: US State-level Panel Analysis. Economies 2017, 5, 30. [CrossRef]

15. Chudik, A.; Pesaran, H.M. Common Correlated Effects Estimation of Heterogeneous Dynamic Panel Data Models with Weakly Exogenous Regressions. J. Econ. 2015, 188, 393-420. [CrossRef]

16. Howarth, R.B.; Schipper, L.; Anderson, B. The Structure and Intensity of Energy Use: Trends in Five OECD Nations. Energy J. 1993, 14, 27-45. [CrossRef]

17. Liu, G. Estimating Energy Demand Elasticities for OECD Countries; Discussion Papers No. 373; Statistics Norway: Kongsvinger, Norway, 2004; pp. 1-27.

18. Narayan, P.K.; Smyth, R.; Prasad, A. Electricity Consumption in G7 Countries: A Panel Cointegration Analysis of Residential Demand Elasticities. Energy Policy 2007, 35, 4485-4494. [CrossRef]

19. Medlock, K.B., III; Soligo, R. Economic Development and End-use Energy Demand. Energy J. 2001, 22, 77-105. [CrossRef]

20. Labandeira, X.; Labeaga, J.M.; López-Otero, X. A Meta-analysis on the Price Elasticity of Energy Demand. Energy Policy 2017, 102, 549-568. [CrossRef] 
21. Cuddington, J.T.; Dagher, L. Estimating Short and Long-run Demand Elasticities: A Primer with Energy-sector Applications. Energy J. 2015, 36, 185-209. [CrossRef]

22. Espey, M. Explaining the Variation in Elasticity Estimates of Gasoline Demand in the United States: A Meta-analysis. Energy J. 1996, 17, 49-60. [CrossRef]

23. Espey, J.A.; Espey, M. Turning on the Lights: A Meta-analysis of Residential Electricity Demand Elasticities. J. Agric. Appl. Econ. 2004, 36, 65-81. [CrossRef]

24. Alberini, A.; Filippini, M. Response of Residential Electricity Demand to Price: The Effect of Measurement Error. Energy Econ. 2011, 33, 889-895. [CrossRef]

25. Santos, G.F. Fuel Demand in Brazil in a Dynamic Panel Data Approach. Energy Econ. 2013, 36, $229-240$. [CrossRef]

26. Berndt, E.R.; Wood, D.O. Technology, Prices, and the Derived Demand for Energy. Rev. Econ. Stat. 1975, 57, 259-268. [CrossRef]

27. Pindyck, R.S. Interfuel Substitution and the Industrial Demand for Energy: An International Comparison. Rev. Econ. Stat. 1979, 61, 169-179. [CrossRef]

28. Smith, C.; Hall, S.; Mabey, N. Econometric Modeling of International Carbon Tax Regimes. Energy Econ. 1995, 17, 133-146. [CrossRef]

29. Sato, M.; Singer, G.; Dussaux, D.; Lovo, S. International and Sectoral Variation in Energy Prices 1995-2011: How Does It Relate to Emissions Policy Stringency? Working Paper, No. 212; Centre for Climate Change Economics and Policy: Leeds, UK, 2015; pp. 1-40.

30. Anderson, T.W.; Hsiao, C. Estimation of Dynamic Models with Error Components. J. Am. Stat. Assoc. 1981, 76, 598-606. [CrossRef]

31. Arellano, M.; Bover, O. Another Look at the Instrumental Variable Estimation of Error-components Models. J. Econ. 1995, 68, 29-51. [CrossRef]

32. Miller, M.; Alberini, A. Sensitivity of Price Elasticity of Demand to Aggregation, Unobserved Heterogeneity, Price Trends, and Price Endogeneity: Evidence from U.S. Data. Energy Policy 2016, 97, 235-249. [CrossRef]

33. Apergis, N.; Payne, J.E. The Emissions, Energy Consumption, and Growth Nexus: Evidence from the Commonwealth of Independent States. Energy Policy 2010, 38, 650-655. [CrossRef]

34. Belke, A.; Dobnik, F.; Dreger, C. Energy Consumption and Economic Growth: New Insights into the Cointegration Relationship. Energy Econ. 2011, 33, 782-789. [CrossRef]

35. Eggoh, J.C.; Bangaké, C.; Christophe, R. Energy Consumption and Economic Growth Revisited in African Countries. Energy Policy 2011, 39, 7408-7421. [CrossRef]

36. Tugcu, C.T.; Ozturk, I.; Aslan, A. Renewable and Non-renewable Energy Consumption and Economic Growth Relationship Revisited: Evidence from G7 Countries. Energy Econ. 2012, 34, 1942-1950. [CrossRef]

37. Organization for Economic Cooperation and Development. OECD Structural Industrial Analysis Database. Available online: https:/ / stats.oecd.org/Index.aspx?DataSetCode=STANi4 (accessed on 8 June 2016).

38. The World Bank. World Development Indicator. Available online: https://datacatalog.worldbank.org/ dataset/world-development-indicators (accessed on 29 April 2018).

39. International Energy Agency. World Energy Statistics Database (Edition 2015). Available online: https://www.oecd-ilibrary.org/energy/data/iea-world-energy-statistics-and-balances/worldenergy-statistics-edition-2015_53d29913-en (accessed on 14 March 2019).

40. International Energy Agency. World Energy Balances Database (Edition 2015). Available online: https:/ / www.oecd-ilibrary.org/energy/data/iea-world-energy-statistics-and-balances/worldenergy-balances-edition-2015_a855e3b2-en (accessed on 14 March 2019).

41. International Energy Agency. Energy Prices and Taxes Statistics Database (Edition 2016). Available online: https:/ / www.oecd-ilibrary.org/energy/data/iea-energy-prices-and-taxes-statistics_eneprice-dataen (accessed on 14 March 2019).

42. Choi, K.-H.; Oh, W. Extended Divisia Index Decomposition of Changes in Energy Intensity: A Case of Korean Manufacturing Industry. Energy Policy 2014, 65, 275-283. [CrossRef]

43. Liddle, B. The Importance of Energy Quality in Energy Intensive Manufacturing: Evidence from Panel Cointegration and Panel FMOLS. Energy Econ. 2012, 34, 1819-1825. [CrossRef]

44. Song, C.; Oh, W. Determinants for Innovation in Energy Intensive Industry and Implications for Energy Policy. Energy Policy 2015, 81, 122-130. [CrossRef]

45. Stata Statistical Software, Release 15; StataCorp: College Station, TX, USA, 2017. 
46. Roodman, D. How to Do xtabond2: An Introduction to Difference and System GMM in Stata; Working Paper No. 103; Center for Global Development: Washington, DC, USA, 2006; pp. 1-48.

47. Roodman, D. A Note on the Theme of Too Many Instruments; Working Paper No. 125; Center for Global Development: Washington, DC, USA, 2008; pp. 1-38.

48. Sargan, J.D. The Estimation of Economic Relationships using Instrumental Variables. Econometrica 1958, 26, 393-415. [CrossRef]

49. Pesaran, M.H.; Smith, R. Estimating Long-run Relationships from Dynamic Heterogeneous Panels. J. Econ. 1995, 68, 79-113. [CrossRef]

50. Chang, B. Price Elasticity of Industrial Sector Energy Demand: Empirical Evidence from OECD Countries. Master's Thesis, Korea University, Seoul, Korea, June 2017.

2019 by the authors. Licensee MDPI, Basel, Switzerland. This article is an open access article distributed under the terms and conditions of the Creative Commons Attribution (CC BY) license (http://creativecommons.org/licenses/by/4.0/). 